\title{
Pandemics and Sustainable Human Nature Relations: A Case study in Baduy Community, South Banten, Indonesia
}

\author{
Johan Iskandar $^{1 *}$ \\ ${ }^{1}$ Lecturer staff at the Department of Biology, Faculty at Mathematics and Natural Sciences, Postgraduate Faculty of Environmental \\ Sciences and Research Staff at CESS (Center for Environment and Sustainability Science), Padjadjaran University
}

\begin{abstract}
In the past, traditional people across cultures in the world in utilizing and managing natural resources and the environment were based on the local knowledge (LK) or Traditional Ecological Knowledge (TEK) and embedded with culture, so that the environment was avoided from damage. Today, as a result of changes in human behavior towards the environment, it has caused various environmental damages and the emergence of pandemic diseases, such as the Covid-19. This article elucidates the relationship between human and natures and environmental changes that have caused emergence of pandemic diseases, including Covid-19. Various efforts have been undertaken by the Indonesian government to cope Covid-19. For example, to prevent the widespread spread of Covid-19 in society, the Indonesian government has recommended every individual to implement the standard health protocols, such as by applying 'three m': menjaga jarak (physical distancing), mencuci tangan dengan sabun (washing hands with soap), and menggunakan masker (wearing masks). Culturally, most of the rural communities in Indonesia initially have a tradition of maintaining health in the family based on local knowledge and strongly embedded by culture, as shown by the traditional people of Baduy community who reside in Village of Kanekes, South Banten. Therefore, the authors suggest that various multidisciplinary and interdisciplinary studies, including the Ethnobiology study, should be carried out more intensively in Indonesia because the results of these studies can be useful for the development of science, and the practical results could be used to integrate with Western scientific knowledge to support various sustainable development programs, such as disaster management, including pandemics that are caused by viruses due to environmental changes..
\end{abstract}

\section{Introduction}

The ecosystem provides services to social system by moving materials, energy and information to social system to meet people's needs. For example, various primary human needs, such as oxygen (O2) for breathing, water for drinking, and various foods from flora and fauna species are supplied by ecosystem services $[39,51]$. In addition, ecosystems also provide various information services to humans. Information can be interpreted as something that gives knowledge to humans, in physical form, color, smell, weather, climate, flora conditions, animal behavior and others. Moreover, the information from the ecosystem by humans is perceived, interpreted, and can influence human decisions to act on the ecosystem. In other words, human actions towards ecosystems and the use of natural resources can be influenced by human knowledge, perceptions and understanding of ecosystems [8, 13, 14, 27, 39].

Actually the traditional communities or local communities in interacting with their environment are usually strongly based on local knowledge (LK) or traditional ecological knowledge (TEK), as well as cosmos or belief $[4,27,54]$. Based on the people's belief that everything in nature is connected. They believe that many events are directly or indirectly a consequence of human actions, beyond human understanding. It is part of their culture to treat nature with careful respect in order to avoid adverse consequences [39].

Because the human population has swiftly increased, the market economic system has rapidly developed, and the flow of communication has quickly changed, it has caused changes in people's views of the environment, as well as changes in human actions towards the environment. Generally, humans have the view that the human self considers himself separate from nature and places himself above nature. They have a Cartesian based thinking, are mechanistic and reductionist modern science, which became the dominant practice of understanding the world $[4,32$, 47]. The environment is seen by humans as objects and tools of human interest. Consequently, nature is exploited by humans unwise, and various environmental damages and the emergence of various ecological disasters, such as floods, landslides, forest fires, air pollution, water pollution, global warming, and the emergence of various infectious diseases globally, including Covid-19 have not been avoided [28, 34]

On the basis of ecological history or environmental history, it has been revealed that the number of disasters in many countries since the beginning of the twentieth

\footnotetext{
* Corresponding author: johan.iskandar@unpad.ac.id
} 
century until now has tended to increase due to human activities that are not wise fronting the environment [7, 34]. For example, the emergence of various contagious diseases globally as a result of being infected with viruses, such as Dengue Fever, Ebola, SARS (Severe Acute Respiratory Syndrome) and the most recent Corona virus (Covid-19), the main causes are the result of human activities, such as destroying or converting forests, and transmission of pathogenic viruses to humans $[43,53]$.

Today with the spread of Covid-19, it has caused some health problems, and even caused death in humans, and caused serious disruption to the socioeconomic and cultural societies in many countries, including in Indonesia [10, 14]. Because of Covid-19, almost all people in urban areas in Indonesia, such as in Jakarta and others, in addition to preventing the transmission of the Covid-19 disease, by following the advice from the government, such as conducting 'the three M', namely 'mencuci tangan dengan sabun' (washing hands with soap), 'menjaga jarak' (maintaining distance), and 'memakai masker' (wearing masks).

In addition, some urban people of Indonesian in maintaining the personal human health and human immunity in the family have been trying to apply the traditional system that used to in the family in the past. For example, they used to drinking herbal medicine from the plant rhizomes of the Zingiberaceae family. Urban residents to meet the needs of Zingeberace's plant species, among others, by buying these plant species at the traditional markets, there are even urban residents who deliberately plant species of Zingiberaceae planted in their homegarden. The reason is, with the presence of Covid-19, they spend more time at home than outside by working from home. The case of urban residents again using traditional medicines, as if they wanted to restore the memory of traditions in society, especially rural communities in the past that to maintain physical health and body immunity for each individual in the family, among others, by drinking herbal medicine made of various plants of Zingiberaceae family, popularly called as herbal jamu.

Indeed, based on the traditions of the Indonesian rural communities in the past, such as the Sundanese people in rural West Java and Banten, to maintain human health and body immunity in each family, it is common to use herbal drinking and to treat illnesses in sick family members, using various medicinal plants, as complementary and alternative medicine (CAM) in society $[2,27,8]$. However, because modern medicines have predominantly traded, the traditional medicine habit uses of society, particularly urban society that is based the local knowledge and is embed with culture are lately eroded.

Today, however, with the emergence of the Covid19 pandemic, many scholars have started to look and want to study the community's traditions in family medicine, such as using medicinal plants, as CAM in the community with the Ethnobiology study approach, so that the results are expected to be used to be integrated with Western scientific knowledge, in order to carry out disease management, such as Covid-19 in an integrated and holistic manner with community participation, to support sustainable development ([17,49].

This article elucidates the human nature relation with regarding with emergence of infectious diseases, including Covid-19 and the tradition of Sundanese people in maintaining the family health and body immunity based on a case study of Baduy community, South Banten, Indonesia.

\section{Human Nature Relation}

Ecosystem can provide various services for the human social system, in the form of energy, material and information to support the needs of human life. For example, for primary daily human needs, including the staple food, water, oxygen (O2), and so on are supplied from the ecosystem services $[22,51]$. Because various primary human needs have been supplied by ecosystem, the human cannot be separated from the ecosystem or environment.

In addition to the flow of energy and matter, humans also obtain a flow of information from ecosystems, in the form of physical objects, colors, sounds, behavior, and others that are received through the human senses. This information is used by humans to manage ecosystems. Conversely, various human activities also flow energy, material and information on ecosystems that have an impact on the ecosystem.

In contrast to other creatures, such as animals, whose interactions with ecosystems are more based on instinct, humans interact with ecosystems using culture [22 41]. Various information from ecosystems by humans with their socio-cultural systems are usually analyzed and interpreted, and made into decisions to act on the ecosystem [39]. In other words, that human action on the environment or ecosystem depends on how the ecosystem is understood and perceived by humans. For local people or traditional people, their actions (praxis) towards the ecosystem are strongly influenced by corpus (knowledge), and cosmos or belief. Therefore, the actions of traditional people towards ecosystems are built by the highly complex system namely CorpusCosmos-Praxis ([4, 6, 22, 27, 54].

Generally since local people have utilized and manage natural resources based on local knowledge and is embedded with culture, the environment can be continuously maintained over time. The behavior of rural communities is also known as ecological wisdom. This ecological wisdom is basically a cultural adaptation of the human population that is obtained from the inheritance of their ancestors and the result of continuous mutual interactions with the ecosystem or its environment. Ecological wisdom is disseminated by people between generations in their communities using their mother language.

Nowadays, however, human actions towards the environment have undergone dramatically changes, so that human actions are not wise towards the environment due to rapid socioeconomic and cultural change and other circumstances affecting the lifestyles and livelihoods of the people [36] . As a result, various environmental damages arise and the emergence of 
various infectious diseases globally caused by viruses $[53,55]$.

\section{Environment destruction and emergence of infectious virus diseases}

Based on ecological history, in recent centuries various infectious virus diseases have emerged globally. For example, from 1880 to 2019, there were no less than 14 infectious diseases globally in the world, namely Malaria (1880), Rift Valley Fever / RVFV- disease of mostly livestock and humans (1931), Dengue Fever (1942), Crimean Congo. Hemorrhagic Fever - CCHV (1944), Zika Fever (1947), Lasa Fever Virus (1950), Chikungunya virus (1953), Marburg hemorrhagic fever (1967), Ebola Virus Disease- EVD (1976), Nipah virus (1998), Severe Acute Respiratory syndrome- SAR (2002), Rift Valley Fever (2010), Middle East Respiratory Syndrome -MERS (2012) and Covid-19Novel Coronavirus- Covid-19 (2019) [37, 42, 53].

The causes of fourteen global infectious diseases in the world are mainly caused by viruses, transmitted by wild animals, such as mosquitoes, bats, primates and others. These various diseases are transmitted to humans mainly due to human behavior that is not wise towards the environment, such as forest encroachment; destroying forests and being converted to other uses, such as agriculture and commercial plantations; and carrying out poaching $[43,53]$.

According to some scholars, there are various factors that cause viruses with animal reservoirs to infect humans, such as Covid-19 in China. This is partly because there is a tradition in Chinese society that Chinese people like to consume wild animals for their diet and it is also believed that various wild animals can be efficacious for traditional medicine systems. Therefore, it is not surprising that in China, it is known, for example, there is a fresh seafood market in Wuhan, Hubei Province, as well as a restaurant that serves various kinds of meat from pets and wildlife, such as poultry, rabbits, bats, snakes, pangolins, turtles, hedgehogs, badgers, and marmot marmots [15].

Some scholars have opinion that the practice of slaughtering and cooking wildlife in China is responsible for spreading the Corona virus from wildlife to humans. This is because, based on the tradition of eating meat from wild animals in China, it is considered more nutritious. However, at the same time, humans may also be infected by various viruses that cause various types of diseases, such as SARS-CoV, Nipah virus, Avian Influenza virus, and others.

Human interactions with wildlife in the market or livestock industry are related to the production of domestic animals, and some time without paying attention to proper environmental biosecurity, have a high risk for humans to be infected by various zoonotic diseases, such as viruses from wildlife to humans in China, especially in the rural communities of southern China [53]. For example, SARS (Severe Acute Respiratory Syndrome) gained international attention during an outbreak that began sometime during November 2001 in China. Wet markets, a known source of influenza viruses since the 1970s, were found to be the source of the bulk of the infections. Live-animal markets, termed 'wet markets,' are common in most Asian societies and specialize in many varieties of live small mammals, poultry, fish, and reptiles. The majority of the earliest reported cases of SARS were of people who worked with the sale and handling of wild animals [53].

Based on the case in China, it can be revealed that the Betacorona virus genus has potential causes of zoonotic pathogens, such as SARS-CoV and MERS$\mathrm{CoV}$ which have bats as primary host and palm civet cat and dromedary camels as intermediate hosts, respectively. The influence of humans destroying the forest environment and hunting wild animals in the forest has led to the spread of infectious diseases by viruses that are spread by wildlife. Almost the same case, based on ecological history, such as the Nipah virus in Malaysia which emerged in 1999 which killed many people. Actually the very dangerous virus Nipah disease arises from reservoir hosts, such as fruit bats and spreads to domestic animals such as pigs as amplifier hosts [43, 53] (Table 1). Forest and human damage is increasing. Activities in the forest for farming, opening commercial plantations and others cause human contact with wildlife, such as bats to intensify and have a high risk of spreading pathogenic viruses from animals to humans [43]. 
Table 1. Infection of diseases and mechanisms of potential changing incidence as related to ecosystem changes

\begin{tabular}{|c|c|c|c|c|c|}
\hline Diseases & Cases per year & $\begin{array}{l}\text { Geographical } \\
\text { distribution }\end{array}$ & $\begin{array}{l}\text { Emergence } \\
\text { mechanism }\end{array}$ & $\begin{array}{l}\text { Anthropogenic } \\
\text { driver }\end{array}$ & $\begin{array}{l}\text { Expected } \\
\text { variation from } \\
\text { ecological } \\
\text { change }\end{array}$ \\
\hline Malaria & 350 million & $\begin{array}{l}\text { Tropical } \\
\text { (America, Asia, } \\
\text { Africa) }\end{array}$ & $\begin{array}{l}\text { Niche invasion; } \\
\text { Vector } \\
\text { expansion }\end{array}$ & $\begin{array}{l}\text { Deforestation; } \\
\text { Water projects }\end{array}$ & Very high \\
\hline $\begin{array}{l}\text { Japanese } \\
\text { Encephalitis Rift } \\
\text { Valley fever }\end{array}$ & $30,000-50,000$ & Southeast Asia & $\begin{array}{l}\text { Vector } \\
\text { expansion }\end{array}$ & $\begin{array}{l}\text { Irrigated rice } \\
\text { field }\end{array}$ & High \\
\hline Dengue fever & 80 million & Tropical & $\begin{array}{l}\text { Vector } \\
\text { expansion }\end{array}$ & $\begin{array}{l}\text { Urbanization, } \\
\text { poor housing } \\
\text { conditions }\end{array}$ & High \\
\hline Ebola & - & Africa & $\begin{array}{l}\text { Forest } \\
\text { encroachment, } \\
\text { bushmeat } \\
\text { hunting }\end{array}$ & $\begin{array}{l}\text { Forest } \\
\text { encroachment }\end{array}$ & Low \\
\hline $\begin{array}{l}\text { Nipah/Hendra } \\
\text { viruses }\end{array}$ & - & $\begin{array}{l}\text { Australia, } \\
\text { Southeast Asia }\end{array}$ & Niche invasion & $\begin{array}{l}\text { Industrial food } \\
\text { production, } \\
\text { deforestation, } \\
\text { climate } \\
\text { abnormalities }\end{array}$ & High \\
\hline SARS & 8,098 & Global & Host transfer & $\begin{array}{l}\text { Intensive } \\
\text { livestock } \\
\text { operations } \\
\text { mixing wild and } \\
\text { domestic } \\
\text { animals }\end{array}$ & Low \\
\hline $\begin{array}{l}\text { Covid-19-Novel } \\
\text { Coronavirus } \\
(\text { Covid-19)*) }\end{array}$ & - & Global & Host transfer & $\begin{array}{l}\text { Intensive animal } \\
\text { hunting and } \\
\text { trading, animal } \\
\text { farm, wild } \\
\text { animal } \\
\text { consumption } \\
\text { and traditional } \\
\text { medicines }\end{array}$ & High \\
\hline
\end{tabular}

Source: Adapted from Patz et al. (2020); *) Tiwari et al. (2020).

It can be seen from Table 1 that the main causes of contagious diseases are caused by human actions, such as destroying animal habitats, hunting and illegal trading of animal species. Today, the relationship between humans and the environment, especially in urban communities, has undergone dramatically changes. However, in some rural communities in Indonesia, there are still many who still care for the environment and maintain health and treat illness by using medicinal plants. While Indonesia has more than 1,000 ethnic / sub-ethnic groups with more than 700 local languages, and has a variety of local ecosystems, Indonesia has an extraordinary wealth of local knowledge and practices of local people in utilizing natural resources and the environment wisely and sustainably [21, 27]. The following description is narrated about the traditions of the traditional Baduy community, in Kanekes Village, South Banten in maintaining health in the family, having knowledge of various diseases and how to treat them, and managing infectious diseases.

\section{Family health care}

The Baduy community, South Banten is one of the

groups of traditional Sundanese people who still want to maintain a tradition like their ancestors, especially in the swidden farming (ngahuma). Some discussions about the practice of the Baduy community in managing the traditional swidden farming system and environmental conservation, especially the forest ecosystem, have been discussed anywhere [23, 26, 24, 30].

The Baduy community besides having a tradition of farming and conserving the forest environment, they also have a tradition of maintaining health and treating various diseases in the family based on Traditional Ecological Knowledge, embedded with culture. The Baduy community to maintain health for each family is generally undertaken by each family, as was generally the Sundanese people in the past. Mothers who are carrying babies and newborns to adulthood are very concerned about their health conditions in a cultural manner. The reason is, traditionally the purpose of life for the Sundanese people, including the Baduy community, has 5 main goals, namely 'healthy' (cageur); 'kind-hearted, honest' (bageur); 'clever' 
(pinter); 'true' (bener); and 'skilled' (singer) (Iskandar 2018).

Traditionally, the Baduy family mother who gives birth is actually assisted by the traditional Birth Attendant (paraji or indung beurang). Although currently some Baduy people, especially the Outer Baduy people, have started to adopt the village midwives (bidan) to help mothers who want to give birth. This is because based on the Indonesian government program that mothers in rural areas who give birth must be assisted by a 'village midwife' rather than being assisted by the traditional Birth Attendant [2, $12]$.

In the Baduy community, a mother who wants to give birth, during childbirth and after giving birth, is usually assisted by the traditional Birth Attendant. When a baby is 7 days old, a traditional ceremony in the form of 'selamatan bayi' is usually held. At the ceremony, a family with has baby invites relatives and neighbors to attend the ceremony. In addition to having a symbolic meaning, the ceremony to celebrate the baby's age for seven days also has an important meaning to maintain the health of newborns and mothers who have just given birth to baby. For example, to help a newborn mother, during the ceremony a herbal concoction made from herbal medicinal herbs is provided, such as konéng gedé (Curcuma xanthorhiza Roxb), konéng leutik (Curcuma domestica), cikur (Kaempferia galangal L), sembung (Blumea balsamifera L (DC), pedes (Piper nigrum L) and cabé Jawa (Piper retrofactum Vahl).

The herbal plant ingredients are pounded, boiled with hot water, and the water (air godogan) is drunk by a new mother. Drinking herbs from these species of herbal plants is usually carried out by a mother giving birth consecutively for 7 days after giving birth. In general, Baduy people believe that new mothers who are given herbal medicine can help restore the health of the baby's mother (Iskandar 2018).

Scientifically, based on the bioactive ingredients contained in these species of herbs are quite beneficial for the health of the human body. For example, the main content of koneng besar (Curcuma xanthoriza Roxb) consists of starch (48.18 -59.64\%), protein (29-30\%), ash (5.26 -7.07\%), fiber $(2.58-4.83 \%)$, curcumin (1.6$2.2 \%$ ) and essential oils (6-10\%). Meanwhile, the various properties of Cucuma xanthoriza include starch which is useful for helping metabolic and physiological processes of the body's organs. The fiber has the benefit of restoring body freshness (tonic in nature). Curcumin to facilitate the body's digestive process. Meanwhile, essential oils can be beneficial for kidney function [3, 9].

In addition, the content of curcumiod in Curcuma xanthoriza can function as anti-bacterial, anti-cancer, anti-tumor, and contains antioxidants. The benefits of Curcuma xanthoriza extract include anti-bacterial properties of Staphyloccocus aureus, Stapyloccocus epidermis, Bacillus cereus, and Sterptococcus mutans [9]. Therefore, based on the scientific that the species of herbal plants, such as Curcuma xanthoriza which are commonly used by the Baduy people do contain substances that are useful for maintaining the health of the human body and can prevent the transmission of various germs, such as species of bacteria.

\section{Various diseases and traditional treatment}

On the basis of the Baduy people' perception, the cause of the illness is caused of various factors, such as due to an outbreak of various kinds of germs, such as viruses, fungi, and bacteria; natural factors such as weather; and caused by human behavior errors, such as violating customary rules (kawalat) (Kurnia and Sihabudin 2010; Iskandar 2018). Generally, the various causes of illness based on Baduy people are similar to other ethnics of Indonesia or Southeast Asia in that it has caused of the germs, natural, spiritual, emotion and psychological, and social causes [27, 31, 40].

Because based on the Baduy perception, the illnesses are considered to be influenced by various factors, the treatment of these diseases must be adjusted to the factors that cause the disease. For example, if someone is illness and the cause of the disease is considered to have violated customary rules, then the treatment needs to be carried out by praying or asking for help from the shaman (dukun) or traditional Baduy leader (Puun) to ask for forgiveness and forgiveness because he/she has violated customary rules. Meanwhile, if based on the Baduy's perception that the disease is caused by natural factors or germs, then the treatment can be done by being treated by various species of medicinal plants. Meanwhile, if the person's illness is considered severe, then the illness sufferer must be taken to the hospital.

Based on the results of the Ethnobiology study conducted in Baduy, it has been revealed 27 diseases/disturbances that commonly afflict the Baduy community (Table 2). To treat various diseases/disturbances, 132 species of medicinal plants, representing 57 families (5 unidentified scientific names) (Table 3 ). 
Table 2. Various diseases/disturbances were documented of the Baduy community, South Banten, Indonesia

\begin{tabular}{|c|c|c|c|}
\hline No & Vernacular term & Indonesian term & English common term \\
\hline 1 & Batuk & Batuk & Cough \\
\hline 2 & Bisul & Bisul & Ulcer \\
\hline 3 & Buuk kotor & Rambut kotor & Dirty hair \\
\hline 4 & Cacingeun & Sakit cacing perut & Intestinal worm \\
\hline 5 & Congé, Totosan & Congek & Ear infection \\
\hline 6 & Dipacok oray & Dipatuk ular & Poisonous snake bite \\
\hline 7 & Eungap, Bengék & Asma & Asthma \\
\hline 8 & Gangguan ngajuru & Pendarahan ibu melahirkan & Bleeding of women after giving birth \\
\hline 9 & Hapur & Panu & Skin fungus infection \\
\hline 10 & Henteu bisa héés & Susah tidur & Insomnia \\
\hline 11 & Kasaléo suku & Kaki terkilir & Ankle sprain \\
\hline 12 & Kulit kasap & Kulit tidak halus & Skin is not smooth \\
\hline 13 & Kurang cai susu & Air susu ibu kurang & Lack of breast milk \\
\hline 14 & Laleuleus awak & Badan letih & No-appetite and exhaustion \\
\hline 15 & Mimisan & Hidung berdarah & Suffer from nose-bleed \\
\hline 16 & Muriang & Demam & Fever \\
\hline 17 & Nyeri beuteung & Sakit perut, diarea & Stomachache, diarrhea \\
\hline 18 & Nyeri hulu & Sakit kepala & Headache \\
\hline 19 & Nyeri huntu & Sakit gigi & Toothache \\
\hline 20 & Nyeri panon & Sakit mata & Sore eyes \\
\hline 21 & $\begin{array}{l}\text { Panas jero, Sariawan, } \\
\text { Barusuh }\end{array}$ & Panas dalam, Seriawan & Sprue \\
\hline 22 & Panyakit konéng & Penyakit kuning, hepatitis & Hepatitis \\
\hline 23 & Paregel awak & Reumatik & Rheumatism \\
\hline 24 & Raheut & Luka & Wound \\
\hline 25 & Susah kiih & Susah kencing & Diuretic problem \\
\hline 26 & Seueul & Mual & Trapped wind \\
\hline 27 & Ubar kuat & Perangsang seks & Aprosodiac \\
\hline
\end{tabular}


Table 3. List of Medical Plants to treat diseases and disturbances of the Baduy Community.

\begin{tabular}{|c|c|c|c|c|c|c|}
\hline No & Vernacular name & Scientific name & Common name & Family & Treatment & $\begin{array}{l}\text { Main part of } \\
\text { plant }\end{array}$ \\
\hline 1 & Angsana & Pteropus indicus Willd & Redsandal wood & Fabaceae & Toothache & Tap of stem \\
\hline 2 & Antanan & Centela asiatica (L) Urb & Asiatic pennyworth & Apiaceae & Diuretic & Leaf and stem \\
\hline 3 & Aren & Arenga pinnata (Wurmb) Merr & Sugar palm & Arecaceae & No-appetite and Exhaustion (Tonic) & $\begin{array}{l}\text { Fermented } \\
\text { Arenga Wine }\end{array}$ \\
\hline 4 & Areuy kacembang & Embelia ribes Burm.f. & False Black Pepper & Primulaceae & Sore eyes & Tap of stem \\
\hline 5 & Areuy kawao & Millettia sericea (Venth) Benth & Creeper Milletia & Fabaceae & Fever & Leaf \\
\hline 6 & Areuy konéng & Arcangelisia flava (L) Merr & $\begin{array}{l}\text { Yellow-fruited moon- } \\
\text { seed }\end{array}$ & Menispermaceae & Trapped-wind & Stem \\
\hline 7 & Areuy palungpung & $\begin{array}{l}\text { Merremia hedaracea (Burm.f) } \\
\text { Hallier.f }\end{array}$ & Ivi-like merremia & Convolvulaceae & Intestinal worms & Tap of stem \\
\hline 8 & Areuy reuteum & & & & Skin irritation & Leaf \\
\hline 9 & Awi apus & $\begin{array}{l}\text { Gigantochloa apus (Schult \& } \\
\text { Schult.f) Kurz }\end{array}$ & String bamboo & Poaceae & Cough & $\begin{array}{l}\text { Tap of stem/inter- } \\
\text { node }\end{array}$ \\
\hline 10 & Awi bitung & $\begin{array}{l}\text { Gigantochloa atter (Hassk) } \\
\text { Kurz }\end{array}$ & Black bamboo & Poaceae & Herbal cosmetic & Leaf \\
\hline 11 & Awi gedé & $\begin{array}{l}\text { Gigantochloa verticillata } \\
\text { (Willd) Munro }\end{array}$ & Giant stripy bamboo & Poaceae & Hair tonic & Tap of stem \\
\hline 12 & Awi hideung & $\begin{array}{l}\text { Gigantochloa atroviolacea } \\
\text { Widaja }\end{array}$ & Black bamboo & Poaceae & $\begin{array}{l}\text {-Hair tonic } \\
\text {-Cough }\end{array}$ & Tap of stem \\
\hline 13 & Awi tamiang & $\begin{array}{l}\text { Schizostachyum silicatum } \\
\text { Widjaja }\end{array}$ & Taming bamboo & Poaceae & Cough & Tap of stem \\
\hline 14 & Barahulu & Amomum aculeatum Roxb & Amomum & Zingiberaceae & Headache & Tap of stem \\
\hline 15 & Bawang bodas & Allium sativum L & Garlic & Liliaceae & Toothache & Bulb \\
\hline 16 & Berenuk & Crescentia cujete L & Calabash tree & Bignoniaceae & Fever & Leaf \\
\hline 17 & Beunying & Ficus fistulosa Reinw ex Bl & Yellow stem-fig & Moraceae & Ulcer & Stem \\
\hline 18 & Bintinu & $\begin{array}{l}\text { Melochia umbellate (Houtt) } \\
\text { Stapf }\end{array}$ & Melochia & Sterculiaceae & Toothache & Tap of stem \\
\hline 19 & Bisoro & Ficus hirta Vahl & Fig & Moraceae & Rheumatism & Inner bark \\
\hline 20 & Bolongeun & & & & Ulcer & Leaf \\
\hline 21 & Bonténg & Cucumis sativus $\mathrm{L}$ & Cucumber & Cucurbitaceae & Herbal cosmetic & Fruit \\
\hline 22 & Bubuay & $\begin{array}{l}\text { Plectocomia elongate Mart ex } \\
\text { Blume }\end{array}$ & Giant Rattan Palm & Arecaceae & Cough & Tap of stem \\
\hline 23 & Cabé Jawa & Piper retrofactum Val & Javanese long pepper & Piperaceae & No-appetite and exhaustion (Tonic & Fruit \\
\hline 24 & Cantigi ketan & Gaulteria leucarpa Blumeu & & Ericaceae & Toothache/tartar on teeth & Stem \\
\hline 25 & Capeu & Blumea balsamifera $(\mathrm{L}) \mathrm{DC}$ & Sambong & Asteraceae & No-appetite and Exhaustion (Tonic) & Leaf \\
\hline
\end{tabular}




\begin{tabular}{|c|c|c|c|c|c|c|}
\hline 26 & Capeu pacikrak & $\begin{array}{l}\text { Erechtites valerianifolia Link } \\
\text { ex Spreng }\end{array}$ & Tropical burnweed & Asteraceae & Headache & Leaf \\
\hline 27 & Cariang & Homalonema cordifolia & & Araceae & Wound & Stem, leaf \\
\hline 28 & Cariang asli & $\begin{array}{l}\text { Homalonema pendula (Blume) } \\
\text { Bakh.f }\end{array}$ & Red arrow-leaf & Araceae & Fever & Leaf \\
\hline 29 & Cariu & Entada phaseoloides (L) Merr & Thomas bean & Fabaceae & No-appetite and Exhaustion (Tonic) & Fruit \\
\hline 30 & Carulang & $\begin{array}{l}\text { Spatholobus ferrugineus } \\
\text { (Zoll.\&Moritzi) Benth }\end{array}$ & & Fabaceae & Hair tonic & Leaf \\
\hline 31 & Cau ambon & Musa $\mathrm{x}$ paradisiaca $\mathrm{L}$ & Banana & Musaceae & No-appetite and Exhaustion (Tonic) & Flower \\
\hline 32 & Cau kolé & Musa paradisiaca L & Forest banana & Musaceae & Antidote of poisonous snake bitten & Flower \\
\hline 33 & Cengek & Capsicum frutescens L & Chili & Solanaceae & Headache & Leaf \\
\hline 34 & Cikur & Kaempferia galanga L & Aromatic ginger & Zingiberaceae & Ankle sprain & Rhizome \\
\hline 35 & Dadap & $\begin{array}{l}\text { Erythrina variegata f.picta (L) } \\
\text { Maheshw }\end{array}$ & Tiger claw & Fabaceae & Sore eyes & Flower \\
\hline 36 & Durian & Durio zibethinus L & Durian & Bombaceae & Diarrhea & Bark \\
\hline 37 & Eurih & $\begin{array}{l}\text { Imperata cylindrical (L) Rae- } \\
\text { usch }\end{array}$ & Cogon grass & Poaceae & Wound & Young stem \\
\hline 38 & Gadung & Diocorea hispida Dennst & Yam & Dioscoreaceae & Insomnia & Leaf \\
\hline 39 & Géhgéran & Mimosa pudica & Common sensitive plant & Fabaceae & Sprue & Root \\
\hline 40 & Ginggiang & Leea aequata $\mathrm{L}$ & & Vitaceae & Ulcer & Leaf \\
\hline 41 & Gintung & Bischoffia javanica Blume & Bishop wood & Phyllanthaceae & Toothache & Sap of stem \\
\hline 42 & Hantap & Sterculia javanica R.Br & & Sterculiaceae & Fever & Leaf \\
\hline 43 & Haremeng & Cratoxylon clandestinum Bl & & Guttiferae & Herbal cosmetic & Leaf \\
\hline 44 & Harendong & Clidemia hirta (L) D.Don & Soap bush & Melastomataceae & Cough & Sap of stem \\
\hline 45 & Harendong & $\begin{array}{l}\text { Melastoma malabaricum (L) } \\
\text { Smith }\end{array}$ & Rhododendron & Melastomataceae & Ulcer & Leaf \\
\hline 46 & Hareueus & Rubus rosaefolius $\mathrm{Sm}$ & Thimbleberry & Rosaceae & No-appetite and Exhaustion (Tonic) & Leaf \\
\hline 47 & Honjé & $\begin{array}{l}\text { Etlingera speciose (Blume) } \\
\text { R.M Smith }\end{array}$ & & Zingiberceae & Skin Irritation- & Rhizome, Stem \\
\hline 48 & Ilat & Scleria purpurascens Steud & Nutrushes & Cyperaceae & Diuretic & Leaf \\
\hline 49 & Jahé & Zingiber oficinale Roscoe & Garden ginger & Zingiberaceae & Cough & Rhizome \\
\hline 50 & Jambé & Areca catechu Burm.f & Betel palm & Arecaceae & $\begin{array}{l}\text {-Hair tonic } \\
\text {-Wound }\end{array}$ & $\begin{array}{l}\text { Stem } \\
\text {-Leaf sheath }\end{array}$ \\
\hline 51 & Jambu batu & Psidium guajava L & Guava & Myrtaceae & Diarrhea & Leaf \\
\hline 52 & Jaringao & Acorus calamus L & Sweet-flag & Acoraceae & Ankle sprain & Leaf \\
\hline 53 & Jawer kotok & Plectranthus galeatus Vahl & & Lamiaceae & $\begin{array}{l}\text {-Hair tonic } \\
\text {-Sprue }\end{array}$ & Leaf \\
\hline 54 & Jeruk nipis & $\begin{array}{l}\text { Citrus aurantifolia (Christm) } \\
\text { Swingle }\end{array}$ & Lime & Rutaceae & Sore eyes & Fruit \\
\hline
\end{tabular}




\begin{tabular}{|c|c|c|c|c|c|c|}
\hline 55 & Jeungjing & $\begin{array}{l}\text { Albizia chinensis (Osbeck) } \\
\text { Merr }\end{array}$ & Chinese Albizia & Fabaceae & Intestinal worm & Sap of stem \\
\hline 56 & Jongé & Emilia sonchifolia (L) DC & Lilac tasselflower & Asteraceae & Ear infection & Leaf \\
\hline 57 & Jukut bau & Ageratum conyzoides L & Bylligoat weed & Asteraceae & Nosebleed & Leaf \\
\hline 58 & Jukut carulang & Eulisine indica (L) Gaertn & Indian crowfruit grass & Poaceae & $\begin{array}{l}\text {-Wound } \\
\text {-Hair tonic }\end{array}$ & $\begin{array}{l}\text {-Leaf, stem } \\
\text {-Stem }\end{array}$ \\
\hline 59 & Jukut galling & $\begin{array}{l}\text { Fimbristilys globulosa (Retz) } \\
\text { Kunth }\end{array}$ & & Cyperaceae & Hair tonic & Leaf \\
\hline 60 & Jukut jampang pait & $\begin{array}{l}\text { Digitaria sanguinalis (Retz) } \\
\text { Kunth }\end{array}$ & & Cyperaceae & Wound & Leaf, Stem \\
\hline 61 & Jukut kibatuk & & & Poaceace & Cough & All part \\
\hline 62 & Jukut pingping kasir & Paspalum scrobilatum L & Ricegrass paspalum & Poaceae & Diuretic & All part \\
\hline 63 & Jukut sariawan & & & & Sprue & All part \\
\hline 64 & Jukut téléng & $\begin{array}{l}\text { Austroeuphatorium inufolium } \\
\text { (Kunth) R.M King \& H.Rob }\end{array}$ & Austroeuphatorium & Asteraceae & Sore eyes & All part \\
\hline 65 & Jukut tiis & Paspalum distichum L & Knotgrass & Poaceae & Fever & All part \\
\hline 66 & Kacapi & $\begin{array}{l}\text { Sandoricum koetjape (Burm.f) } \\
\text { Merr }\end{array}$ & Santol & Meliaceae & No-appetite and Exhaustion (Tonic) & Leaf, Root \\
\hline 67 & Kacapiring & Gardenia augusta (L) Merr & Cape jasmine & Rubiaceae & Fever & Leaf \\
\hline 68 & Kedondong & Spondias pinnata (L.f) Kurz & Wild mango & Anacardiaceae & Herbal cosmetic & Leaf \\
\hline 69 & Kelapa héjo & Coconut nucifera L & Coconut & Arecaceae & Diarrhea & Bark \\
\hline 70 & Kanyéré & Bridelia monoica (Lour) Merr & & Phyllantaceae & $\begin{array}{l}\text {-Head ache } \\
\text {-Diarhea }\end{array}$ & $\begin{array}{l}\text {-Leaf } \\
\text {-Leaf }\end{array}$ \\
\hline 71 & Kasungka & Gnetum latifolium Blume & & Gnetaceae & Intestinal Worms & Sap of steam \\
\hline 72 & Karas tulang & $\begin{array}{l}\text { Chloranthus erectus } \\
\text { (Buch.Ham) Verdc }\end{array}$ & & Chloranthaceae & No-appetite and Exhaustation (Tonic) & Stem \\
\hline 73 & Katépéng & Cassia alata L & Candle bush & Fabaceae & Skin Irritation & Leaf \\
\hline 74 & Tiwu endog & Saccharum edule Hasskrl & & Poaceae & Tonic for baby & Inner Stem \\
\hline 75 & Kalayaran & Trichosanthes tricuspidata Lour & & Cucurbitaceae & No-appetite and exhaustion (Tonic) & Leaf \\
\hline 76 & Kélor & Moringa olifera Lam & Horse radish tree & Moringaceae & Increasing breast milk & Leaf \\
\hline 77 & Tangkur & Lpohaterium gracile Brongn & $\begin{array}{l}\text { Odora and slender } \\
\text { poreleaf }\end{array}$ & Poaceae & Aphrodisiac & Root \\
\hline 78 & Kisaat & Naucle excels (Blume) Merr & & Rubiaceae & To stop bleeding of women after giving birth & Leaf \\
\hline 79 & Kidangdeur & Bombax ceiba $L$ & Red silk cotton tree & Malvaceae & No-appetite and exhaustion (Tonic) & Stem \\
\hline 80 & Kiencok & Plumbago zeylanica L & Wild leadworth & Plumbaginaceae & Rheumatism & Leaf \\
\hline
\end{tabular}




\begin{tabular}{|c|c|c|c|c|c|c|}
\hline 81 & Kikoréjat & Isotoma longiflora & & Campanulaceae & $\begin{array}{l}\text {-Headache } \\
\text {-Cough }\end{array}$ & $\begin{array}{l}\text {-Leaf } \\
\text {-Sap of stem }\end{array}$ \\
\hline 82 & Kilaja & & & & Cough & Sap of stem \\
\hline 83 & Kilého & Saurauia pendula Blume & & Actinidiaceae & Wound & Sap of stem \\
\hline 84 & Kiparé & $\begin{array}{l}\text { Glochidion obscurum (Roxb.ex } \\
\text { Willd) Blume }\end{array}$ & & Phyllantaceae & Diarrhea & Leaf \\
\hline 85 & Kipoék & $\begin{array}{l}\text { Pithecelobium clipearia (Jack) } \\
\text { Benth }\end{array}$ & Monkey-pod & Fabaceae & Headache & Leaf \\
\hline 86 & Kisabrang & Peronema conescens Jack & & Lamiaceae & No-appetite and exhaustion & Leaf, Stem \\
\hline 87 & Kiseureuh & Piper aduncum $\mathrm{L}$ & Bamboo piper & Piperaceae & Sore eyes & Tap of stem \\
\hline 88 & Kiungkluk & Chromolaena odorata L.R.M & Siam weed & Asteraceae & Wound & Leaf \\
\hline 89 & Konéng & Curcuma longa $\mathrm{L}$ & Common turmeric & Zingiberaceae & Hepatitis & Rhizome \\
\hline 90 & Konéng émbé & Curcuma purpurascens Blume & & Zingiberaceae & Herbal cosmetic & Rhizome \\
\hline 91 & Konéng gedé & Curcuma xanthorhiza Roxb & Javanese ginger & Zingiberaceae & No-appetite and exhaustion (Tonic) & Rhizome \\
\hline 92 & Konyal & Pasiflora edulis & Passion fruit & Passifolraceae & $\begin{array}{l}\text {-Duarhea } \\
\text {-Headache }\end{array}$ & Leaf, Stem \\
\hline 93 & Kunci & Kaempferia angustifolia & Aromatic ginger & Zingiberaceae & No-appetite and exhaustion & Leaf, Stem \\
\hline 94 & Laja & Languas galanga $\mathrm{L}$ & Greater galangal & Zingiberaceae & Wound & Rhizome \\
\hline 95 & Lalangkapan & Wedelia blifora (L.) DC & Beach sunflower & Asteraceae & Sprue & Leaf \\
\hline 96 & Lamé & Alstonia scholaris (L.) R.Br & Indian pulai & Apocynaceae & No-appetite and exhaustion (Tonic) & Stem \\
\hline 97 & Lempuyang & Zingiber odoriferum Blume & & Zingiberaceae & No-appetite and exhaustion (Tonic) & Rhizome \\
\hline 98 & Leuksa & Ficus septica Burm.f & Septic fig & Moraceae & Sore eyes & Sap of stem \\
\hline 99 & Leungsir & $\begin{array}{l}\text { Pomea pinnata J.R. Forst \& } \\
\text { G.Forst }\end{array}$ & & Sapindaceae & Herbal cosmetic & Leaf \\
\hline 100 & Limus & Mangifera odorata Griff & Kuwini & Anacardiaceae & No-appetite and exhaustion (Tonic) & Leaf \\
\hline 101 & Malati & Jasminum sambac (L) Aiton & Arabian jasmine & Oleaceae & Asthma & Leaf \\
\hline 102 & Nangka walanda & Annona muricata L & Soursop & Annonaceae & Fever & Leaf \\
\hline 103 & Nangsi & $\begin{array}{l}\text { Villebrunea rubsecens (Blume) } \\
\text { Blume }\end{array}$ & & Urticaceae & Fever & Leaf \\
\hline 104 & Pacing & $\begin{array}{l}\text { Costus speciosus (J.Koenig) } \\
\text { Sm }\end{array}$ & Costus & Costaceae & Antidote of poisonous & Leaf \\
\hline 105 & Paku kapal & $\begin{array}{l}\text { Pleocnemia irregularis (C.Persl) } \\
\text { Holttum }\end{array}$ & & Dryopteridae & $\begin{array}{l}\text {-Diarrhea } \\
\text {-Sprue } \\
\text {-Ankle sprain }\end{array}$ & Leaf \\
\hline
\end{tabular}




\begin{tabular}{|c|c|c|c|c|c|c|}
\hline 107 & Panglay & Zingiber cassumunar Roxb & Cassumunar ginger & Zingiberaceae & Diarrhea & Rhizome \\
\hline 108 & Paréngpéng & Croton argyratus Blume & & Euphorbiaceae & Sore eyes & Sap of stem \\
\hline 109 & Pecah beling & $\begin{array}{l}\text { Strobilanthes phyllostachyus } \\
\text { Kurz }\end{array}$ & & Acanthaceae & Fever & Leaf \\
\hline 110 & Pedes & Piper nigrum & Black pepper & Piperaceae & No-appetite and exhaustion (Tonic) & Fruit \\
\hline 112 & Pisitan & Lansium domesticum Corréa & Langsat & Meliaceae & No-appetite and exhaustion (Tonic) & Bark \\
\hline 113 & Pungpurutan & Mikania cordata (Burm.f) & Heartleaf hempvine & Asteraceae & Ankle sprain- & Leaf \\
\hline 114 & Rané & $\begin{array}{l}\text { Selaginella plana (Desv.ex } \\
\text { Poir) Hieron }\end{array}$ & & Selaginellaceae & Wound & Leaf \\
\hline 115 & Ranji & Dialium indum L & & Fabaceae & Herbal cosmetic & Leaf \\
\hline 116 & Rambutan acéh & Nephelium lappaceum L & Rambutan & Sapindaceae & Fever & Leaf \\
\hline 117 & Randu & Ceiba pentandra (L.) Gaertn & Kapoktree & Bombacaceae & Fever & Leaf \\
\hline 116 & Reundeu carat & $\begin{array}{l}\text { Staurogyne elongata (Nees) } \\
\text { Kuntze }\end{array}$ & & Acanthaceae & Sprue & Leaf \\
\hline 118 & Rinu & Piper cubeba L.f & Cubeb & Piperaceae & Cough & Fruit \\
\hline 119 & Rukem & Flacourtia rukam Zoll & Rukam & Salicaceae & Sore eyes & Leaf \\
\hline 120 & Saga & Abrus precatorius $\mathrm{L}$ & Rosary pea & Fabaceae & Cough & Sap of stem \\
\hline 121 & Salak & Salacca edulis (Gaertner) Voss & Salak palm, Snake palm & Palmae & Fever & Leaf \\
\hline 122 & Salam & $\begin{array}{l}\text { Syzigium polyanthum (Wight) } \\
\text { Walp }\end{array}$ & Indian Bayleaf & Myrtaceae & Sprue & Leaf \\
\hline 123 & Sembung & Blumea balsamifera (L) DC & Nagi camphor & Asteraceae & No-appetite and exhaustion (Tonic) & Leaf \\
\hline 124 & Sempur & Dilenia obovate & & & Wound & Inner bark \\
\hline 125 & Seureuh & Piper betle L & Betel pepper & Piperaceae & -Nosebleed, Sore eyes & Leaf \\
\hline 126 & Singugu & Clerodendron serratum L & & Verbenaceae & Hepatitis & Leaf \\
\hline 127 & Tangkal sariawan & $\begin{array}{l}\text { Symplocos odoratissima } \\
\text { (Blume) Choisy ex Zoll }\end{array}$ & & Symplocaeae & Sprue & Leaf, Stem \\
\hline 128 & Teureup & $\begin{array}{l}\text { Ficus elasticus Roxb ex Hor- } \\
\text { mem }\end{array}$ & Indian rubber fig & Moraceae & Skin irritation & Bark \\
\hline 129 & Tepus & Zingiber spectabile Griff & Tepus & Zingiberaceae & Cough & Sap of stem \\
\hline 130 & Tiwu hideung & Saccharum officinarum L & Sugar cane & Poaceae & Diuretic & Stem \\
\hline 131 & Tomas & $\begin{array}{l}\text { Codiaeum variegatum (L) } \\
\text { Rumph ex.A.Juss }\end{array}$ & Croton & Eyphorbiaceae & Fever & Leaf \\
\hline 132 & Wéra & Malvaviscus arboreus (Oct) & Max wallow & Malvaceae & Fever, Cough & Leaf \\
\hline
\end{tabular}

Source: Field research (1994/1995); (2013); Ginanjar (1997) 
Based on the number of species of medicinal plants commonly used by Baduy people, the species number is more than the number that of commonly used by the Kesupuhan community, the traditional community of neighboring Baduy, who live around Mount Halimun National Park, Cisolok, South Sukabumi, West Java, was recorded 117 species of medicinal plants commonly used by the Kasepuhan community [20]. However, the number of medicinal plant species in Baduy is smaller than that of commonly used by the Dayak Kenyah Leppo'ke community, Pujungan sub-district, East Kalimantan (today North Kalimantan Province), with 192 medicinal plant species were recorded [19]. The number of medicinal plants in the Dayak Kenyah Leppo'ke community, Pujungan Sub-district may be higher because of its more remote location so that it is difficult for the rural people to get modern medicine from the city and the market economy influence from the city is very low, and the area still has quite extensive forests. Therefore, the forest area is still predominantly planted with medicinal plants.

Among the various species of medicinal plants in the Baduy community (Table 3), several species, including Amomum aculeatum Roxb, Curcuma domestica L, Curcuma xanthoriza Roxb, Zingiber cassumunar Rox, Zingiber odoriferum Blume and Zingiber oficinale Roscoe are belonged to Zingeberaceae family that are predominantly used for herbal refreshments and body enhancers or body immunity, as well as the treatment of diseases, such as cough, hepatitis, and diarrhea (Table 4). a healthy condition, but there are also times when people suffer from illness. So, if a person is stricken with illness, the cause of the illness is sought. If the illness is due to wrong human behavior, such as violating customary rules. Thus, the illness cannot be treated, such as by types of traditional medicinal plants, but must be treated by the informal leader of the Baduy community (Puun) or a traditional healer. For example, people who violate the customs in Baduy, especially Inner Baduy, usually perform a ceremony led by Puun or his staff in Inner Baduy.

In addition, according to the Baduy tradition, in carrying out the life of the Baduy people, apart from maintaining health (cageur), they also have to behave properly based on customary law (pikukuh). Living right and the honest, among others, must obey various pikukuh. For example, based on the Baduy customary law, the Baduy community must conserve their environment, which the area considers as sacred land and is a deposit from their ancestors. Therefore, in Baduy there are various customary rules that must be obeyed by every Baduy people [25], as follow:

- They are not allowed to dig soil;

- They are prohibited to plant monoculture commercial crops, including clove;

- They are not allowed to raise buffalo, cattle, sheep and goat; and

- They are prohibited to apply synthetic chemical pesticides and inorganic fertilizers, poison fish and wildlife in their practicing the swidden cultivation.

Table 4. Various medical plants of Zingiberaceae family are commonly used by the Baduy community

As can be seen that the concept of the Baduy

\begin{tabular}{|c|c|c|c|c|}
\hline No & $\begin{array}{l}\text { Scientific } \\
\text { name }\end{array}$ & $\begin{array}{l}\text { Vernacular } \\
\text { name }\end{array}$ & $\begin{array}{l}\text { Common } \\
\text { name }\end{array}$ & $\begin{array}{l}\text { Traditional } \\
\text { use }\end{array}$ \\
\hline 1 & $\begin{array}{l}\text { Amomum } \\
\text { Acualetum } \\
\text { Roxb }\end{array}$ & Barahulu & Amomum & $\begin{array}{l}\text { For cough medicine, use the 'barahulu' taps of stem and its } \\
\text { water is used for treating caught }\end{array}$ \\
\hline 2 & $\begin{array}{l}\text { Curcuma } \\
\text { domestica L }\end{array}$ & Konéng & $\begin{array}{l}\text { Common } \\
\text { turmeric }\end{array}$ & $\begin{array}{l}\text { For the drug hepatitis medicine, use rhizome of 'koneng' is } \\
\text { pounded and boiled, and drink the water. }\end{array}$ \\
\hline 3 & $\begin{array}{l}\text { Curcuma } \\
\text { Xanthoriza } \\
\text { Roxb }\end{array}$ & $\begin{array}{l}\text { Koneng } \\
\text { gedé }\end{array}$ & $\begin{array}{l}\text { Javanese } \\
\text { ginger }\end{array}$ & $\begin{array}{l}\text { For body healthy herbs and to maintain and improve the health } \\
\text { of mothers who have just been giving birth. The technique of } \\
\text { making it is like making traditional herbal medicine, rubbing it } \\
\text { on the body accompanied by a traditional ceremony when the } \\
\text { baby is seven days old }\end{array}$ \\
\hline 4 & $\begin{array}{l}\text { Zingiber } \\
\text { Cassumunar } \\
\text { Roxb }\end{array}$ & Panglay & $\begin{array}{l}\text { Cassumunar } \\
\text { ginger }\end{array}$ & $\begin{array}{l}\text { Panglay mixed with sweet-flag leaves, shallots, garlic, and } \\
\text { black pepper is dried and ground until soft and becomes flour } \\
\text { and used to be rubbed on the body for freshness. }\end{array}$ \\
\hline 5 & $\begin{array}{l}\text { Zingiber } \\
\text { odoriferum } \\
\mathrm{B} 1\end{array}$ & Lempuyang & & $\begin{array}{l}\text { For refreshing herbs for tired bodies. The procedure for making } \\
\text { it is mixed with other plants, such as ginger, see the next } \\
\text { description of the use of ginger. }\end{array}$ \\
\hline 6 & $\begin{array}{l}\text { Zingiber } \\
\text { officinale }\end{array}$ & Jahé & $\begin{array}{l}\text { Garden } \\
\text { ginger }\end{array}$ & $\begin{array}{l}\text { For cough medicine, how to use it ginger rhizome is crushed } \\
\text { mixed with a little water and drunk by cough sufferers. In } \\
\text { addition, it is used for refreshing herbs for tired bodies, the } \\
\text { procedures for making it are in the form of rhizome ingredients } \\
\text { of ginger mixed with capeu leaves (Blumea balsamifera Merr), } \\
\text { and rhizomes of lempuyang (Zingiber odoriferum } \mathrm{B1} \text { ), singugu } \\
\text { leaves (Clerodendrom serratum Spreng), and cikur } \\
\text { (Kaempferia galanga } \mathrm{L} \text {.), koneng (Curcuma domestica } \mathrm{L} \text { ) are } \\
\text { pounded and boiled and the water is drunk. }\end{array}$ \\
\hline
\end{tabular}

community to achieve human health, the need to protect the environment so that it is healthy, not damaged, also includes the need to protect animals and animal habitats (animal health), then this is very much in line with the scientific concept, namely to achieve healthy humans, the need for 'one health system', namely human health, environmental health, and animal health [55].

As mentioned earlier each Baduy family must maintain health, both physical health and spiritual health. They believe that in human life there is always a change and balance, such as sometimes human life is in 


\section{Traditional management of infectious diseases}

Actually the Baduy community has a system of adaptation and mitigation to the risk of disasters of infectious diseases based on the traditional Ecological Knowledge (TEK) strongly embedded with culture, such as belief. According to informants of the Baduy community, it can be seen that in the 1960 s, in some areas in West Java and Banten, malaria was spread due to the plasmodium parasite spread by the anopheles mosquito. At that time many people died as a result of contracting malaria. To eradicate the malaria disease, in 1963 the Indonesian government established a malaria eradication command program (KOPEM-Komando Pembasmi Malaria). Through the KOPEM program, the Anopheles mosquito, which is a vector of malaria, is mass eradicated by spraying with an organochlorine pesticide, Dichloride Diphenyl Trichloroethane (DDT). Today, DDT is prohibited to be used in Indonesia. This is because DDT can pollute the environment because it is difficult to decompose in nature.

In 1964 the KOPEM program was generally successful in eliminating malaria in Indonesia. Although in general malaria was successfully eradicated, at that time there were other infectious diseases, such as smallpox that had not been eradicated, especially in the Baduy area. Therefore, West Java provincial KOMPEM officers came and interviewed the traditional leaders of the Baduy community in Kanekes Village to find out and at the same time eradicate the disease. Based on the results of interviews with KOPEM officers with Baduy traditional leaders (Puun), it can be seen that Baduy people have special management of smallpox contagious disease. Culturally, if there are Baduy people who are infected with smallpox (panyakit kuris in Baduy term). People suffering from smallpox must be quarantined or exiled to forest areas outside the settlement. The reason is, according to the perception of the Baduy community (emic's view), a person with smallpox who is isolated in a forest area, while being exiled he/she will wage war against the evil creature that causes smallpox. If a person with smallpox who is being exiled in the forest does not die, it means that he/she has won against an evil creature, then he is allowed by the Baduy customary leader (Puun) to return to the village and reunite with his core family at home.

As can be seen at the practice of controlling smallpox by the Baduy people, it is quite in line with the principles of Western scientific knowledge (ethical view), that smallpox is caused by the Varicella zoster virus. To avoid spreading smallpox to other citizens, sufferers must be isolated, by being placed separately from other individuals.

The habit of managing infectious diseases of Baduy people is based on culture is similar that of commonly practiced by traditional hunters and gatherers, "Suku Anak Dalam' community who live in the forest area of Jambi, Sumatra. Based on the tradition of the Suku Anak Dalam community, if a family member is illness and dies in their temporary house (dangau), they must move to a new area and set up a dangau in a new place [52]. In principle, moving places by the Suku Anak Dalam community if a family dies from an infectious disease can be interpreted as a forest people strategy so that the disease will not spread to other healthy people.

Meanwhile, in relation with the outbreak of Covid19 in Indonesia since March 2019 [10], the Baduy community has developed a mitigation and adaptation strategy for the spread of Covid-19 to the Baduy area, South Banten. For example, the Baduy people discipline followed the orders of the Baduy traditional leaders (Puun) and the formal village head (Jaro Pamarentah). Based on orders from customary leaders and formal village leaders that during the outbreak of Covid-19, each Baduy person is prohibited from going to the city, especially cities known categorized as 'red zones', such as Jakarta, Tangerang, Bekasi, Depok and Bogor. Meanwhile, Baduy people who are wandering in the city are required to return home and before they return to their village in the Baduy area, Kanekes Village, they must have their health conditions checked at the Community Health Service Center (Puskesmas) (Wismabrata 2020).

In addition, to mitigate and adapt to the Covid-19 pandemic, so that the disease does not enter the Baduy village, the Baduy community also implements traditional methods combined with scientific methods, namely implementing a model of Baduy lockdown system, closing the area visited by outsiders through kawalu ceremonies. Each year after the rice harvest, the Baduy people usually carry out the kawalu ceremony three times, on different months. The first kawalu is done in the month of Kasa (January-February). The second kawalu is held in the month of Karo (FebruaryMarch), and the third kawalu is in the month of Katiga (March-April). During these months the Baduy people usually fast every time the kawalu ceremony, so they fast three days or three times, in 3 different months [26]. However, unlike the Muslim fast during Ramadan, the Baduy is embedded strongly in the practice of swidden cultivation. Baduy fast for only three days, after the harvesting of rice, rather than for the full month of the Muslim fast. The first, second and the third kawalu are called kawalau kahiji, kawalu tengah and kawalu tutug, respectively.

Two days before upacara kawalu in Outer Baduy (Baduy Luar), there are various preparatory activities for the ritual. For example, all family each hamlet work together to clean their houses, as well as underneath the houses. This is called 'beberesih kampung'. Rubbish and dust are swept using rice stalk brooms (sapu pare) and a rag. Weed growth surrounding the house is removed using a bush knife (arit). All the rubbish is collected and thrown into a special place at the back of the house (kolomberan). In addition, the communal bathing place (pancuran) is repaired: old bamboo pipes are replaced with new ones, and footpaths leading to the pancuran improved and terraced using river stones. The rice barns are also improved in a similar way [23].

During the kawalu ceremony, visitors from outside Baduy, such as visitors from the city, are prohibited from visiting the Baduy area. Therefore, the tradition of closing the Baduy area during the kawalu ceremony was used by the Baduy community for mitigation and adaptation of the spread of Covid-19 to their village 
brought by tourists from the city who visited the Baduy area. In other words, with the kawalu ceremony in the Baduy area, the Baduy area will be locked down, and can play an important role in mitigating efforts to prevent the transmission of Covid-19 to the Baduy area.

Generally with the existence of Covid-19, the habit of villagers to carry out mitigation based on local knowledge is closely combined with Western scientific knowledge, as is done by the Baduy, which is also carried out by villagers in other places. For example, cases of revitalization and hybridization of local knowledge and Western scientific knowledge for Covid19 migration were also found in the community of Ngablak Village, Cluwak District, Pati Regency, Central Java [1]. In the past, the people of Ngablak Village had a tradition that everyone who returned after traveling was encouraged to clean themselves before entering the house. This is so that the negative energy carried by a person's body when traveling is not carried away into the house. The rural community in Pati of Central Java (Wong Pati) believes that humans live surrounded by a variety of invisible positive and negative energies. When traveling, a person can unconsciously come in contact with various negative energies which can sometimes have a negative influence on a person. Therefore, someone who has just returned from traveling must clean himself so that negative energies from outside do not enter the house where he lives, and have a negative effect on the life of someone who occupies the house. Wong Pati calls this negative energy sawan, people who are exposed to sawan are called sawanen. When people are sawanen, usually that person will get illness for reasons that are not clear. The symptoms you feel are different, what often happens is a sudden fever.

In the past every family of Ngablak Village had a padasan that was placed outside the house. The padasan word is taken from the padusan which means a place to clean oneself. This padasan is usually a barrel (gentong) made of clay and has a small hole at the bottom so that water can flow through the hole. The main function of this padasan is to clean yourself before entering the house. In addition, padasan also functions as a place for wudlu before performing prayers for Muslims. In addition to washing your feet and hands is also aimed to everybody who enters the house is clean.

Because new houses have been built, the tradition of providing padasan in the front of the houses have been forgotten and not been applied any more. Several reasons for leaving the habit of keeping padasan in front of the house, including the high price of a barrel made of clay, and a narrow of the homegarden of the constructed new houses.

Today, however, with occurring the Corona-19 pandemic in Indonesia, the concept of padasan system is revitalized by rural people of Ngablak Village. The people realized that what their ancestors exemplified in the past provided important benefits for the villagers. However, unlike the past, nowadays padasan is no longer a barrel made of clay soil, rural people usually install water channels with pipes and taps that are placed in front of the house near the entrance, or next to the house. This water pipe tap is functioned almost the same as the padasan function in the past, but is now modified to appropriate with current conditions. For example, around the water tap pipe, it is provided with soap. In general, the people of Ngablak Village not only use hand washing soap, but also usually provide various soaps, including bath soap and dish soap that are used for washing.

It can be seen the phenomenon in Ngablak Village, the concept of padasan that has been preserved since the past has continued to be interpreted by its supervisor, namely members of the Ngablak Village community until now. Even though the meaning of the function is still the same, the forms and procedures for cleaning oneself such as washing hands and washing feet continue to be interpreted as the conditions that occur today. In other words, mitigation procedures for the Covid-19 disease disaster are carried out by integrating local knowledge and Western scientific knowledge, which is considered appropriate with current conditions.

Some studies cross-culture in the world also show that it is important to integrate local knowledge and Western scientific knowledge for natural resource management and the environment or disaster mitigation $[5,21,28,29,45,46,56]$. Therefore, multi-disciplinary and interdisciplinary studies, such as ethnobiology and ethnoecology, are important to do intensively, because the results are important for the development of science and practical results can be used to support the sustainable development programs, such as conservation of nature, adaptive agricultural development to various environmental changes, and management of infectious diseases [28].

\section{Conclusion}

This article discusses the case of changing the relationship between humans and their environment. In the past, the traditional population had a view of 'biocentrism' - respect for living things or eco-centrism - everything in nature is connected - with the use of natural resources and the environment based on 'local knowledge' and cosmos or beliefs. Nowadays, however, there is a change, some people, especially urban people, have a view of "anthropocentrism", namely environmental ethics that views humans as the center of the universal system. Humans and their interests are considered the most decisive in order with nature, either directly or indirectly $[4,32]$.

The effect of changing human's word view on nature which is anthropocentrism has caused human behavior towards the environment to change. Thus, the extinction or loss of local knowledge (LK) or traditional ecological knowledge (TEK) and the absence of a belief system or cosmos of the local people towards the environment, have resulted in natural resources being exploited intensively and have caused various environmental damage. The cause consequence of increase in various environmental damages is to raise various natural disasters, such as floods, landslides, droughts, extinction of flora and fauna, and the emergence of global infectious diseases, including Covid-19 [28]. 
Because the global infectious diseases have increased due to human bad behavior towards environment, such as destroying animal habitats, hunting and illegal trade in animal species, to maintain human health it is necessary to be maintain healthy environmental and animal health conditions or "one health approach [55].

An important factor for achieving a "one health approach" is the need for changes in human behavior, such as to achieve "human health" the need to change the behavior of individuals in the family to pay attention to the health of each individual and each family. In addition, to achieve 'environmental health' it is necessary to change human behavior in their interactions with the environment, namely the need to avoid various human behaviors that damage the environment. Meanwhile, to achieve "animal health", it is necessary to change human behavior in interacting with wild animal species, for example to avoid destroying the habitat of wild animal species and avoiding illegal hunting of wild species, as well as the need to pay attention to biosecurity.

In addition, for environmental management, including management of infectious disease disasters, the need to hybridize local knowledge and Western scientific knowledge, and it needs to actively involve local communities, and it should be integrated into sustainable development programs. Therefore, with efforts to manage disease disasters in an integrated manner in a sustainable development program, it will be more guaranteed to achieve the success of the program than a disease disaster management program that is topdown, partial, does not involve local people, and is more short-term project-based.

Conflict of interest: The author declares no conflict of interest.

\section{Acknowledgments}

This research has been supported in the part of the Academic Leadership Grand (ALG) of Prof.Johan Iskandar of Padjadjaran University. I would like to thank the Rector of Padjadjaran University who has supported the ALG Program. I also would like to thank to Baduy village leaders as well as the respondents of Baduy community who assisted and provided valuable information regarding traditional medicinal aspects of Baduy community.

\section{References}

1. Alfian RL. (2020). The Concept of padasan in Javanese homes in the past and present. Internal Report of ALG Program of Ethnobiology, the Department of Biology, Faculty of Mathematics and Natural Sciences, Unpad, Bandung [Indonesian].

2. Ambaretnani P. (2012). Paraji and bidan in Rancaekek: integrated medicine for partnerships among traditional birth attendants and community midwives in the Sunda Region of West Java,
Indonesia. Leiden Ethnosystems and Development Program (LEAD) Studies No.7, Leiden University, Leiden.

3. Anand P. (2007). Bioavailability of curcumin: problem and promises. J.Mol.Pharmaceutic 4 (6): 807-18.

4. Berkes F. (2012). Sacred ecology. Third Edition. Routledge, New York and London.

5. Bollard HL, Fernandez-Gimenez MF, Surtevant VE. (2008). Integration local ecological knowledge and conventional science: a study of seven community-based forestry organizations in the USA. Ecology and Society 13 (2):37. http://www.ecology and society.org/vol 13/iss2/art37/ .

6. Carlson TJS, Maffi L. (2004). Introduction: ethnobotany and conservation of biocultural diversity. In Carlson and Maffi L (eds), Ethnobotany and conservation of biocultural diversity. The New York Botanical Garden Press, Bronx, New York, pp.1-6.

7. Collins AE. (2009). Disaster and development (Routledge Perspectives on Development). First Edition. Routledge, London.

8. Cotton CM. (1996). Ethnobotany: principles and applications. John Willey \& Sons. Chichester, England.

9. Dermawati DE. (2015). Potential extract curcuma (Curcuma xahoriza L) as anti-bacterial. J.Majority 4 (1): 5-11.

10. Djalante R, Lassa J, Setiamarga D, Sudjatma A, Indrawan M, Haryanto B, Mahfud C, Sinapoy MS, Djalante

11. S, Rafliana I, Gunawan L, Sutiari GAK, Warsilah. (2020). Review and analysis of current responses to COVID-19 in Indonesia: period of January to March 2020. Progress in Disaster Science 6 (2020) 100091.

12. Elgasani M, Iskandar BS, Iskandar J. (2020). Health services based on kinship in hamlet of Palintang, village of Cipanjalu, sub-district of Bandung, Province of West Java. Prolife 7 (2): 171-187 [Indonesian].

13. Ellen RF. (1994). Putting plants in their place: anthropological approaches to understanding the ethnobotanical knowledge of rainforest populations. Presentation, UBD-RGS Conference.

14. Ellen RF and Fukui K (eds). 1994. Beyond nature and culture: cognition, ecology and Domestication. Berg, London.

15. El Zowalty ME, Jarhult JD. (2020). From Sars to Covid-19: A previously unknown SARS-related coronaries (SARS-Cov-2) of pandemic potential interacting humans-call for a one health approach. One health 9 (2020) 100124. https://doi/10.1016/j.onehlt 2020.100124.

16. Filho WL, Brandli L, Salvia AL, Rayman -Bachus LL, Platje J. (2020). Communication, Covid-19 and sustainable development goals: treat to 
solidarity or an opportunity?. Sustainability 12: 114. doi:10.3390/su12135343.

17. Franco FM, Bussmann RW. (2020). Rising to occasion: outlining Ethnobiologists response to coronavirus (Covid-19) Pandemic. Ethnobotany research \& applications 20:06 (2020). http://dx.doi.org/10.32859/era.20.06.1-4.

18. Ginanjar I. (1997). Study on plant diversity and uses as medicinal plants in forest of Baduy community, South Banten. Internal report of the Department of Biology, Faculty of Mathematics and Natural Sciences, Padjadjaran University (Indonesian).

19. Gollin LX. (2004). Subtle and profound sensory attributes of medicinal plants among the Kenyah Leppo'ke of East Kalimantan, Borneo. Journal of Ethnobiology 24 (2):173-201.

20. Harada K, Rahayu M, Muzakkir A. (2002). Medicinal plants of Gunung Halimun National Park, West Java, Indonesia. BPC-JICA, Bogor.

21. Hiwasaki L, Luna E, Syamsidik, Shaw R. (2014). Process for integrating local and indigenous knowledge with science for hydro-meteorological disaster risk reduction and climate change adaptation in coastal and small island communities. International Journal of Disaster Risk Reduction 10:15-27.

22. Ingold T. (2000). The Perception of the environment: essay on livelihood, dwelling and skill. Routledge, London and New York.

23. Iskandar J. (1998). Swidden cultivation as a form of cultural identity: The Baduy case. Ph.D. thesis, University of Kent at Canterbury (Unpublished).

24. Iskandar J. (2012). Baduy swidden farming ecology: based on sustainable customary-forest management.Penerbit Alumni, Bandung [Indonesian].

25. Iskandar J. (2017). Human ecology and sustainable development. PSMIL, Bandung, Indonesian.

26. Iskandar J. (2007). Response to environmental stress in the Baduy swidden system, South Banten, Java. In Ellen R (ed), Modern crises and traditional strategies: local knowledge in Island Southeast Asia. Berghahn Books, New YorkOxford, pp.112-132.

27. Iskandar J. (2018). Ethnobilogy, ethnoecology and sustainable development . Plantaxia, Yogyakarta, Indonesian.

28. Iskandar J. 2020. Integrating local knowledge in disaster risk management for application in the Sustainable Development Programs. In Balia RL \& Hendarmawan (eds), Pentahelix Collaboration in the Covid-19 Pandemic Period in an Environmental and Development Perspective. Unpad Press, Bandung [Indonesian].

29. Iskandar J and Ellen RF. (2007). Innovation, 'hybrid' Knowledge and the conservation of relict rainforest in upland Banten. In Ellen RF (ed), Modern crises and traditional strategies: local knowledge in Island Southeast Asia. Berghahn Books, New York-Oxford, pp.133-142.

30. Iskandar J, Iskandar BS. (2016). EthnoastronomyThe Baduy agricultural calendar and prediction of environmental perturbations. Biodiversitas 17 (2): 694-703.

31. Jaspan M.A. (1976). The Social organization of indigenous and modern medicinal practices in Southwest Sumatra. In Lisley C (ed), Asian medical systems: a comparative study. California University Press, California, pp.227-242.

32. Keraf AS. (2002). Environmental ethic. Penerbit Buku Kompas, Jakarta, Indonesian.

33. Kurnia A and Sihabudin A. (2010). Saatnya Baduy Bicara. Bumi Aksara, Jakarta.

34. Lovejoy TE and Hannah. (2020). Changing the biosphere. In Lovejoy TE and Hannah L (eds), Biodiversity and climate change: transforming the biosphere. Yale University Press, New Haven \& London, pp.3-11.

35. Mackinson S. (2001). Integrating local and scientific knowledge: an example in fisheries science. Environmental Management 27 (4): 533545.

36. Maffi L. (2004). Maintaining and restoring biocultural diversity: the evolution of a role for ethnobiology. In In Carlson and Maffi L (eds), Ethnobotany and conservation of biocultural diversity. The New York Botanical Garden Press, Bronx, New York pp.9-35.

37. Malik YS, Sircar S, Bhat S, Vinodhukmar OR, Tiwari R, Sah R, Rabaan AA, Rodriquez-Maorales

38. AJ, Dama K. (2020). Emerging coronavirus disease (Covid-19), a pandemic public health emergency with animal linkages: current status update. Preprint. Doi:10.20944/preprints202003.0343.v1.

39. Marten GG. (2001). Human ecology: basic concepts for sustainable development. Earthscan Publications Ltd, London.

40. Masanori Y. (1985). Indigenous healers and healing: their persistence and vitality in Southeast Asia. Journal of African Studies 29: 232-248.

41. Milton K. (1996). Environmentalism and cultural theory: exploring the role of anthropology in environmental discourse. Routledge, London and New York.

42. Ohimain EI. (2017). Research article: emerging pathogens global significance; priorities for attention and control. EC Microbiology 5.6: (2017):215-240.

43. Patz JA, Confalonieri EC, Amerasinghe FP, Daszak P, Hyatt AD, Molymenk, Thomson M,

44. Yasneogo L, Lazaro MM, Vasconcelo SP, RubioPalis Y, Campbell-Lendrum D, Jaenisih T, Mohamat H, Mutero, Walter-Toews D, Jaenisih T, Mohamat H, Mutero, Walter-Toews D, Whitemen C. 2005. Ecosystem and human- 
wellbeing: current state and trends Vol.1, Island Press, Washington.

45. Prasetyo N. (2019). The Role of traditional knowledge and practices for marine ecotourism development in Misool Raja Ampat, Indonesia. Ph.D.,thesis, University Otago, New Zealand.

46. Raymond CM, Fazey I, Reed MS, Stringer LC, Robinson GM, Evely A. (2010). Integra local and scientific knowledge for environmental management. Journal of Environmental Management 91:1766-1777.

47. Shiva V. (2016). Who really feeds the world?. The failures of agribusiness and the promise of agroecology. North Atlantic Books, Berkeley, California.

48. Slikkerveer LJ. (2006). The Challenge of nonexperimental validation of MAC plants: Towards a multivariate model of transcultural utilization of medicinal, aromatic and cosmetic plants. In Bogers RJ, Craker LE, Lange D (eds), Medicinal and Aromatic Plants: Agricultural, Commercial, Ecological, Legal, Pharmacological and Social Aspects. Springer, Dordrecht, pp.1-28.

49. Soldati GT and Barros FB.(2020). The COVID-19 Pandemic and future of ethnobiology.

50. Ethnobiology and Conservation (2020), 9:17(15 May 2020). doi:10.15451/ec2020-05-9.17-1-4.

51. Suparlan P. (2005). Culture and Development. In Rudito B, Salam A, Rahmiati L, Amini R, Nurlina R, Nuridin (eds), Sustainable Future. ICSD, Jakarta.

52. Takidin. (2014). Wisdom value local culture of Orang Rimba: Study in ethnic minority of Rimba community in Air Hitam Sub-district, Jambi Province. Sosio Didaktika 1 (2): 161-170.

53. Tiwari R, Dhama R, Sharun K, Yatoo MI, Malik YS, Sing R, Michalak I, Sah R, Bonilla-Aldana DK, Rodriguez-Morales AJ, 2020. Review Covid 19: Animals Veterinary and Zoonotic Links. Veterinary Quarterly 40 (1): 169-182.

54. Toledo VM.(2002). Ethnoecology: A Conceptual framework for the study of indigenous Knowledge of nature. In Stepp JR, Wyndham FS, and Zarger RK (eds), Ethnobiology and biocultural. The International Society of Ethnobiology, Georgia.

55. WWF International. 220. The Loss of nature and rise of epidemics: protecting human and planetary health. Gland, Switzerland.

56. Zalfadrim, Toyoda Y, Kanege H.(2019). Integration of indigenous knowledge for disaster risk reduction practices through scientific knowledge: cases from Mentawai Islands, Indonesia. International Journal of Disaster Management 2 (1): 1-12.) 